\title{
Two Year Duration of B.Ed. and M.Ed. Courses: Constrains and Expected Solutions
}

\author{
Dr Jayendrakumar N. Amin ${ }^{1 *}$
}

\section{ABSTRACT}

This paper explores immediate constrains and its expected solutions of two year B.Ed. and M.Ed. programme carried out in Gujarat and particularly in India. The Justice Verma Commission had suggested wide range reforms in Teacher Education which the new Regulations 2014 have addressed. Under the light of Justice Verma commission report and resulting NCTE regulation 2014, the major constrains are faculty, financial crunches, and enhancement of infrastructural facilities on the part of govt. as well as self-financing teacher education institutions. The aspirant students seeking admission in teacher education programme are burdened with heavy fee with the extended duration which ultimately ceases them to pursue their desired course. These and many other constrains are taken into discourse for their better solutions for the betterment of the teacher education.

Keywords: Teacher Education (B.Ed. And M.Ed.), Constrains and Expected Solution.

As stated by NCTE (1998) in Quality Concerns in Secondary Teacher Education-The teacher is the most important element in any educational program. It is the teacher who is mainly responsible for implementation of the educational process at any stage. This shows that it is imperative to invest in the preparation of teachers, so that the future of a nation is secure.

Quality and excellence are prerequisites for any educational institution to create outstanding teacher for betterment of the nation. There is an overwhelming concern about the quality of education especially in the developing countries like India. Kothari commission (1964-66) clearly held that the quality, competence and character of teachers to be the most significant factors, influencing the quality of education and its contribution to national development. Quality school education holds doubtlessly the direct outcome of quality of teachers and the teachers' education system. Indian teacher education has gone through a sea change in many dimensions over the time.

\footnotetext{
${ }^{1}$ Associate Professor, M.Ed. College, Vadu

*Responding Author

(C) 2016 I J Amin; licensee IJIP. This is an Open Access Research distributed under the terms of the Creative Commons Attribution License (http://creativecommons.org/licenses/by/2.0), which permits unrestricted use, distribution, and reproduction in any Medium, provided the original work is properly cited.
} 
Estimates prepared by the National University of Educational Planning and Administration (NUEPA) and the Ministry of Human Resource Development (MHRD) show that implementation of the RTE Act would require the appointment of 0.51 million additional elementary school teachers over and above the existing vacancies of 1.26 million elementary school teachers. The task of ensuring the supply of required number of qualified teachers to the school system within the stipulated time as per the RTE Act remains a principal challenge. Unevenness of the situation across different states makes it even more complicated.

Demand for qualified teachers over the next few years would be substantial especially in the context of RTE Act. It becomes extremely critical for States to expand the current institutional capacities, not only of infrastructure but also of qualified and trained faculty.

The crucial developments and swift advances in the field of education and training of teachers create huge number of challenges for the teacher educators and institutions.

\section{Recommendations of Verma Commission}

The Verma Commission recommended total 30 recommendations for Teacher Education Institutions and Strengthening NCTE. The few striking Recommendations are as follows:

$>$ Teacher education should be a part of the higher education system. The duration of programme of teacher education needs to be enhanced.

$>$ Every pre-service teacher education institution may have a dedicated school attached to it as a laboratory where student teachers get opportunities to experiment with new ideas and hone their capacities and skills to become reflective practitioners.

$>$ The institutional capacity should be increased for preparation of teacher educators. There is a need to make the Masters in Education programme of 2-year duration with the provision to branch out for specialization in curriculum and pedagogic studies, foundation studies, management, policy and finance, and other areas of emerging concerns in education.

$>$ The NCTE would need to develop broad based norms for qualification of teacher educators to enable induction of persons with post graduation degrees in education science, social sciences, languages and mathematics, along with a professional degree in teacher education or a research degree in education, as teacher educators.

NCTE completed and notified the revised Regulations 2014, along with Norms and Standards for 15 programmes on November 28, 2014 under Government of India Gazette Notification No.346 (F.No. 51-1/2014/NCTE/N\&S) by following the recommendations of the Justice Verma Commission (JVC) appointed by the Government at the instance of the Hon'ble Supreme Court of India. The JVC had suggested wide range reforms in Teacher Education which the new Regulations 2014 have addressed. Under the light of Justice Verma commission report and resulting NCTE regulation 2014, the major constrains and its expected solutions can be expressed as follow: 


\section{Major Constrains:}

In one year B.Ed. programme 8(1+7) full time faculty members were required for 100 students, whereas; with the increase of duration in B.Ed. course up to two years, $16(1+15)$ full time faculty members are required for 100 students (2 basic units of 50 students). The same is increased in M.Ed. course too. Essential arrangements for fulfilling the post (including financial liability) are to be done before implication of this regulation-State Govt. (for Govt. and Govt. aided colleges) and College concerned (for self financed colleges). There is a dearth of qualified staff in teacher education. Increase in duration demands more qualified staff but, unavailability of qualified staff will further deteriorate the quality of teacher education. Especially self-financed teacher education institutes with their nexus with affiliating university will further confirm on record that they didn't find the qualified staffs, which ultimately create the situation more pitiful. Intake capacity (M.Ed.) for Basic unit of 35 students which was further increased to 50 students (only one unit/Institution) which accentuates on enhancement of infrastructural facilities. This disheartens the present teacher education institution to continue as they are reluctant to invest more for quality teacher education.

New Teacher Education Institution has to be located in composite Institutions and the existing teacher education Institutions shall continue to function as stand-alone Institutions; and gradually move towards becoming Composite Institution. Infrastructural facilities will be enhanced accordingly. It is not fully viable for self-financing and some college to move smoothly in this setting.

As the course increase in duration, it puts extra financial burden on students in the form of fees to be paid, so the entrants become reluctant in getting admission in teacher education course. The situation ultimately hampers the process of producing qualified teachers and teacher educators.

The concept of learning without burden is confiscated with the enhancement in duration. Since; it demands four semester-end examinations in place of two in previous version. In the prevailing system of examination in higher education, this will promote cramming among prospective teachers and will further carry on where they are deployed in school or college system. The internship without any monetary reward which falls in fourth semester will obstruct the quality parameter of teacher education.

\section{Expected solutions:}

It is imprudent to enhance merely the duration of the teacher education courses. As the quality don't have any direct relation solely on duration of time in teacher training. This can be achieved by maintaining timely admission and with the maximum utilisation of time allocated for the teacher education course. If one year time duration is utilised with commitment and with rigour, quality teachers can be prepared.

The following solutions, if implemented with cent percent commitment by each teacher education institutions, one year teacher education programme can produce excellent teachers as it does: 
$>$ As the Justice Verma committee had an objection of compromised quality in teacher education institutions in all respect in the country, a stricter periodical surprised monitoring system should be strictly followed from three levels-NCTE, state govt. and university.

$>$ Each teacher education institute (B.Ed./M.Ed. or other form) ought to recruit qualified teacher educators.

$>$ The basic infrastructure needs should be maintained as per the NCTE norms and there should not be any compromise with it.

$>$ Imparting education should be considered as a social service instead of considering a profit making firm.

$>$ Instead of making the present institutes as composite institutes, the B.Ed. /M.Ed. programme should be worked out in the present pattern of formal higher education.

$>$ Internship should be kept in the last semester and it should have some monetary reward for prospective teachers.

$>$ There will be four semester end examinations with enhancement of two year duration which are not advisable for preparing quality teacher. B.Ed./ M.Ed. programme duration can be kept one year with a separate six month paid internship.

\section{CONCLUSION}

These are the few suggestions, if carried out properly, a quality teacher education can be ensured in the country. The entire episode was due to the deteriorate quality prevailing in the teacher education institutes. It is the duty of every teacher education institution in the country to introspect and maintain quality at each level_from recruitment to imparting quality teacher training to prospective teachers.

\section{REFERENCES}

Kothari, D. S. (Chairman) (1966). Report of the Education Commission 1964-66, Vol.1. Govt. of India, New Delhi. Retrieved from http://www.dise.in/ Downloads/KothariCommissionVol.1pp.1-287.pdf

MHRD (2012). Vision of Teacher Education in India Quality and Regulatory Perspective. Retrieved from http://mhrd.gov.in/sites/upload_files/mhrd/files/ documentreports/JVC\%20Vol\%201.pdf

NCERT (1978). National Curriculum Framework of Teacher Education. Author, New Delhi. NCERT (1988). National Curriculum Framework of Teacher Education. Author, New Delhi. NCTE (1998). National Curriculum Framework for Teacher Education. Author, New Delhi. NCTE (2009). National Curriculum Framework for Teacher Education. Author, New Delhi. 